\title{
Arsenic, Chromium, and Other Potentially Toxic Elements in the Rocks and Sediments of Oropos-Kalamos Basin, Attica, Greece
}

\author{
D. Alexakis ${ }^{1}$ and D. Gamvroula ${ }^{2}$ \\ ${ }^{1}$ Laboratory of Reclamation Works and Water Resources Management, School of Rural and Surveying Engineering, \\ National Technical University of Athens, 9 Iroon Polytechniou Street, 15773 Athens, Greece \\ ${ }^{2}$ Institute of Mineralogy-Geology, Agricultural University of Athens, 75 Iera Odos, 11855 Athens, Greece \\ Correspondence should be addressed to D. Alexakis; dial@survey.ntua.gr
}

Received 10 January 2014; Accepted 30 March 2014; Published 6 May 2014

Academic Editor: Artemi Cerda

Copyright (C) 2014 D. Alexakis and D. Gamvroula. This is an open access article distributed under the Creative Commons Attribution License, which permits unrestricted use, distribution, and reproduction in any medium, provided the original work is properly cited.

\begin{abstract}
Rocks and sediments are non-anthropogenic sources of elements contamination. In this study, a series of potentially toxic elements were quantified in rocks and sediments of the Oropos-Kalamos basin. Only As, $\mathrm{Hg}, \mathrm{Pb}$, and $\mathrm{Sb}$ contents, in all the examined rocks and sediments, were higher than the levels given in international literature. Concentration of the elements $\mathrm{As}, \mathrm{Cr}, \mathrm{Hg}, \mathrm{Mo}, \mathrm{Ni}$, and $\mathrm{U}$ is highly elevated in the lignite compared to crustal element averages. The enrichment of $\mathrm{Cr}$ and $\mathrm{Ni}$ in the lignite can be attributed to the known ultramafic rock masses surrounding the basin, while enrichment of As, $\mathrm{Hg}, \mathrm{Mo}$, Sb, and $\mathrm{U}$ is associated with the past geothermal activity of the Upper Miocene (about 15 million years ago). Nickel and Cr were transported into the lignite deposition basin by rivers and streams draining ultramafic rock bodies. The results of this study imply the natural source of $\mathrm{Cr}^{3+}$ and $\mathrm{Cr}^{6+}$ contamination of the Oropos-Kalamos groundwater, since high $\mathrm{Cr}$ contents were also recorded in the lignite $\left(212.3 \mathrm{mg} \mathrm{kg}^{-1}\right)$, chromiferous iron ore occurrences $\left(256.6 \mathrm{mg} \mathrm{kg}^{-1}\right)$, and alluvial deposits $\left(212.5 \mathrm{mg} \mathrm{kg}^{-1}\right)$, indicating Cr leaching and transportation to the depositional basin dating from the Upper Miocene age.
\end{abstract}

\section{Introduction}

Many chemical compounds, major elements, and trace metals appear in waters and soils through agricultural, industrial, municipal activities, and natural processes [1-7]. In this way, there is an increase in the number of research studies dealing with degradation of water and soil quality [8-14], as well as with the levels of elements in vegetables [15] and biological samples [16]. Since, according to Salomons [17], $99.9 \%$ of the metals are stored in soils and sediments, the high storage capacity of these materials plays an important role in controlling the fate and transport of the metals. Based on these fundamentals, the investigation of the composition of soils-sediments-rocks is very important to determine the natural influences on water quality.

A previous study concerning the groundwater quality of the Oropos-Kalamos basin has been conducted by
Stamatis et al. [14]. In that study elevated contents have been recorded for the following trace elements: As, Co, Cr $\mathrm{r}_{\text {total }}$, $\mathrm{Cr}^{6+}, \mathrm{Mn}, \mathrm{Pb}, \mathrm{U}$, and $\mathrm{V}$ in the groundwater of OroposKalamos basin. Furthermore, Stamatis et al. [14] applied speciation analysis and statistical treatment techniques in order to identify the factors controlling the elevated element contents in Oropos-Kalamos groundwater without, however, mentioning or investigating the composition of the representative solid materials (rocks, sediments, and soils) outcropping in the area studied.

The aim of this paper is, firstly, to evaluate the occurrence of trace elements in the representative samples from regional rocks and sediments, and, secondly, to define relationships between the trace element contents in the system: rocksediment-groundwater.

Needless to say, that risk assessment of trace element contamination has become an important research topic 
dealing mainly with food quality and safety, health-related issues in humans, and environmental issues throughout the world. Recent developments in the field of risk assessment include research studies by:

(i) Komnitsas and Modis [18], who assessed the risk related to As and $\mathrm{Zn}$ contamination in a coal mining region using variography analysis and numerical modelling;

(ii) Komnitsas and Modis [19], who estimated the risk at waste disposal sites in the presence of hotspots;

(iii) Vacca et al. [20], who investigated the total content of heavy metals in contaminated soils of the Rio Sitzerri floodplain (Sardinia, Italy) and discussed their impact on pedodiversity;

(iv) Roy and McDonald [21], who studied the metal uptake in plants and assessed the health risk in metalcontaminated smelter soils;

(v) Fernández-Calviño et al. [22], who studied the spatial variability of total copper, exchangeable copper, and bioavailable copper in a vineyard soil by applying statistical and geostatistical methods.

The results of this study will assist the local decision makers and regulators, firstly, to better understand the processes controlling the migration of trace elements into the OroposKalamos basin and, secondly, to reduce environmental risk by selecting the best management practices.

\section{Materials and Methods}

2.1. Description of the Study Area. The study area lies between latitudes of $38^{\circ} 14^{\prime}-38^{\circ} 21^{\prime}$ and longitudes of $23^{\circ} 44^{\prime}-23^{\circ} 52^{\prime}$ (Figure 1), being about $50 \mathrm{~km}$ north from Athens, the capital of the Greek Republic. It has an area of $80 \mathrm{~km}^{2}$ approximately.

Geological formations which are observed in the study area include (Figure 2) schists, limestones, volcanosedimentary formations, chromiferous iron ore occurrences, ultramafic rock masses, flysch, conglomerates, marly limestones with travertines, marly formations with lignite intercalations, and alluvial deposits [23-25]. The geology and lithology of the Oropos-Kalamos basin have been extensively presented in our previous study [14].

Corine land cover was used for obtaining the land use data [26]. The land use of the study area was classified into the following categories (Figure 3): (1) urban, (2) agricultural, (3) forest, shrub, and sparse vegetation, and (4) wetlands. The area studied includes the villages of Skala Oropou, Nea Palatia, Asprochori, Milesi, Mavrosouvala, and Kalamos and the cities of Oropos and Markopoulo. The agricultural land in Oropos-Kalamos basin is characterized by intensive agricultural activities especially vineyards, vegetables, and olive oil trees (Figure 3). Extensive lignite mining has occurred in the southeastern part of the study area since 1870 up to the 1960s. As a result of the mining activities, great amounts of waste produced from lignite mining activities were deposited in piles around the mining areas (Figure 3). There is a lack of industrial activities in Oropos-Kalamos basin.

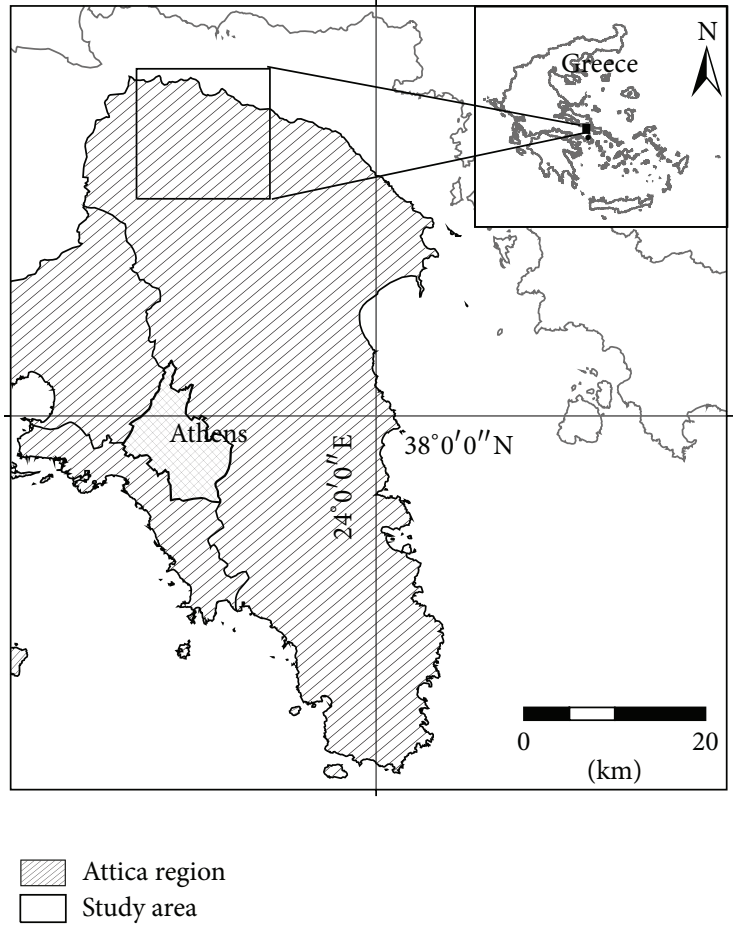

FIGURE 1: Location map of the area studied.

2.2. Sampling and Laboratory Procedures. The rock-sediment sampling program was conducted with a total of eleven (11) sampling sites (Figure 2). During the sampling process simultaneous site surveys were carried out in order to provide site specific information relating to industrial and agricultural activities near the sampling sites. Sampling sites were recorded in the field by using a Garmin eMap geographical positioning system (GPS). Rock and sediment bulk samples were collected from different lithological formations in order to be representative of the solid phases in contact with groundwater. Each sample collected comprised at least five subsamples that were homogenized into a single bulk sample which was about $2 \mathrm{~kg}$. Specifically, two bulk samples were collected from lignites (RS1 and RS2), two bulk samples were taken from chromiferous iron ore occurrences (RS3 and RS4), two bulk samples were collected from marly formation (RS5 and RS6), three bulk samples were taken from conglomerates (RS7, RS8, and RS9), and two bulk samples were collected from alluvial deposits (RS10 and RS11) (Figure 2).

Bulk lignite samples were collected from the abandoned lignite mines vicinity. The surface of sampling sites was cleaned from vegetation and superficial debris before sampling by using a polypropylene tool and the samples were stored into clean polyethylene (PE) bags. Marly and conglomerate formation samples were taken from rock surface by using a hammer. The bulk lignite, chromiferous iron ore, marly, and conglomerate formation samples were airdried at room temperature $\left(<25^{\circ} \mathrm{C}\right)$, crushed, and grounded to $<0.200 \mathrm{~mm}$. Furthermore, the rock and sediment samples were quartered prior to chemical analysis. Contact with metals was avoided throughout samples preparation to 


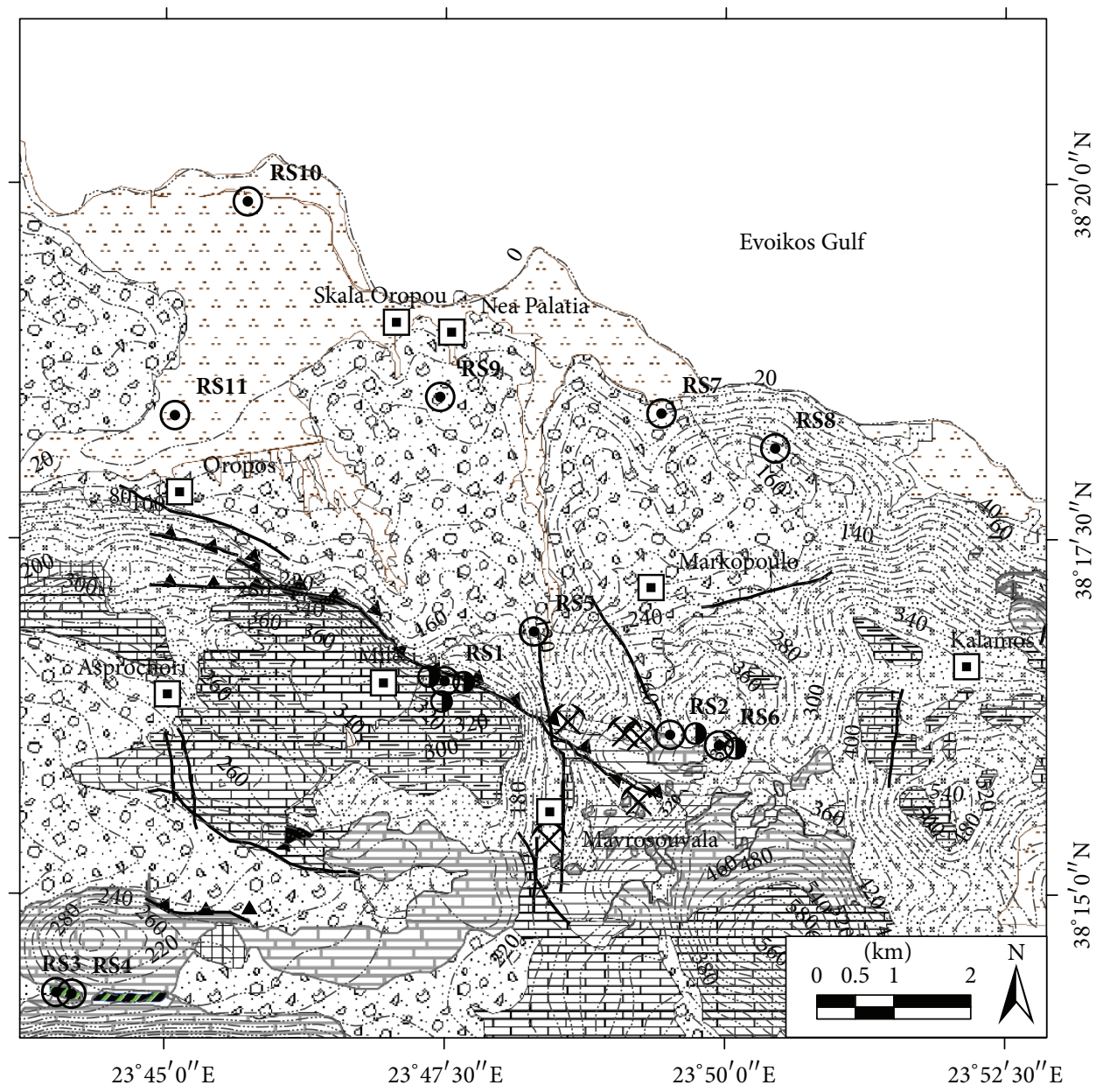

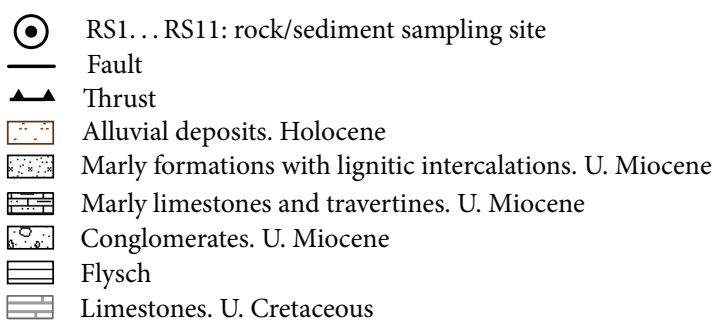

Excavated lignite ore
Lignite tailings
City/village
Ultramafic rock masses
Chromiferous iron ore occurrences
Volcano-sedimentary formations
Limestones. Triassic-Jurassic
Schists with psammitic rocks
Schists. U. Jurassic

Figure 2: A simplified geological map of the Oropos-Kalamos area $[23,25]$ showing lignite tailings, excavated lignite ore occurrences, and sampling sites.

avoid metal contamination. The homogenized and pulverized samples were digested with a mixed-acid attack employing concentrated $\mathrm{HNO}_{3}$ and concentrated $\mathrm{HCl}$. The resulting solutions were analyzed for $\mathrm{Cd}, \mathrm{Co}, \mathrm{Cr}, \mathrm{Cu}, \mathrm{Fe}, \mathrm{Mn}, \mathrm{Pb}$, and $\mathrm{Zn}$ by atomic absorption spectroscopy method (AAS) using a GBC 908AA model at the Laboratory of Geology of the Agricultural University of Athens and for Ag, Al, As, $\mathrm{Au}, \mathrm{B}, \mathrm{Ba}, \mathrm{Bi}, \mathrm{Ca}, \mathrm{Ga}, \mathrm{Hg}, \mathrm{K}, \mathrm{La}, \mathrm{Mg}, \mathrm{Mo}, \mathrm{Na}, \mathrm{Ni}, \mathrm{P}, \mathrm{S}$, $\mathrm{Sb}, \mathrm{Sc}, \mathrm{Se}, \mathrm{Sr}, \mathrm{Te}, \mathrm{Th}, \mathrm{Ti}, \mathrm{Tl}, \mathrm{U}, \mathrm{V}$, and $\mathrm{W}$ by inductively coupled plasma mass spectrometry (ICP-MS) at the ACME Analytical Laboratories Ltd., Vancouver, Canada (ISO 9002 Accredited Co.). Chemical analyses were monitored by using reference samples of the National Institute of Standards and
Technology. Montana soil reference sample SRM 2710 was routinely analyzed to determine analytical errors (accuracy 5-9\%). Triplicate measurements were conducted for $10 \%$ of the analyzed samples (precision 2-4\%).

Homogenized and pulverized representative rock and sediment subsamples were made into pressed powder pellets and analyzed by powder X-ray diffraction (XRD) using an automated Siemens D5005 diffractometer. The scanning electron microscopic (SEM) analysis was used as a complementary technique with XRD analysis. Representative sediment and rock subsamples were examined by using a SEM model JEOL JSM-5600. An energy dispersive X-ray detector (EDX) Oxford Link ISIS 300 was used for the 


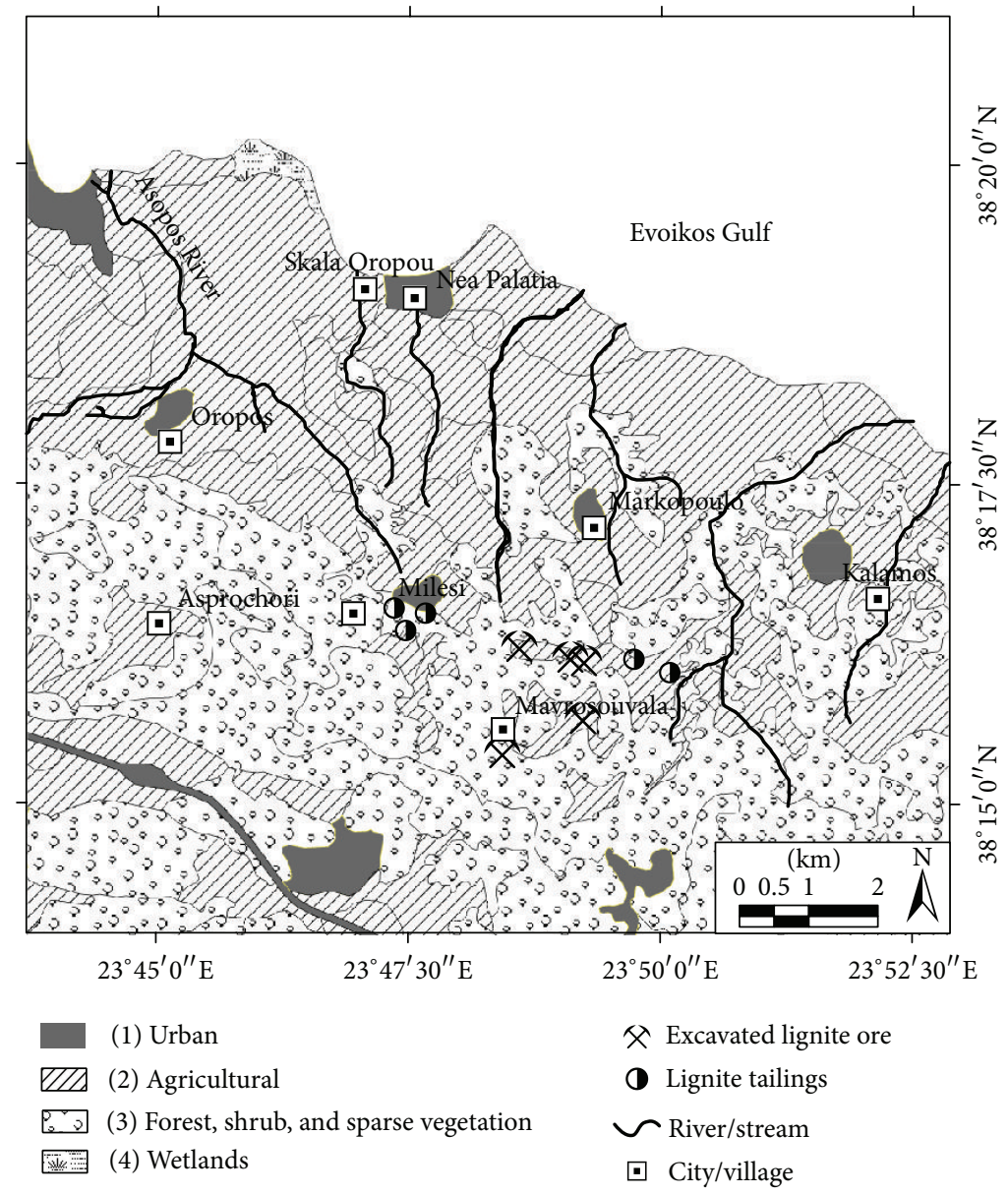

FIGURE 3: Map showing the land uses of the study area, rivers, streams, and names of the cities and villages.

qualitative analysis of some spots of the rock and sediment samples. The XRD and SEM analysis were performed at the Laboratory of Economic Geology and Geochemistry, National and Kapodistrian University of Athens. Minerals were identified on the basis of morphology and SEM-EDX chemistry.

2.3. Statistical Treatment and Spatial Analysis. The geochemical data were treated using the Microsoft Excel software package. A geographic information system (GIS) platform was created using ArcGIS 10.0 software (ESRI). The GIS platform includes basic layers showing the lithology, rivers, streams, and cities/villages locations. Sampling site locations, lignite tailings, and excavated lignite ore occurrences have been also plotted on additional information layers of the GIS.

\section{Results and Discussion}

The mineral phases detected in the bulk lignite samples by $\mathrm{XRD}$ analyses are calcite, illite, gypsum, and montmorillonite. The XRD analysis of chromiferous iron ore occurrences was dominated by chlorite, illite, iron oxides, montmorillonite, and quartz, while ankerite and dolomite were detected in the marly formation samples.
The SEM observation and microanalysis results indicated the presence of calcite, organic matter, and pyrite in the bulk lignite samples as framboids and as isolated euhedral forms (Figure 4). The SEM examination of the chromiferous iron oxide samples shows the presence of chromite, hematite, illite, and quartz (Figure 5).

Since Cr-Ni bearing minerals were not detected by XRD of bulk lignite samples, indicating that their concentrations are below the detection limits $( \pm 2 \mathrm{wt} \%)$ of the analytical technique, it is possible that some of the $\mathrm{Cr}$ and $\mathrm{Ni}$ have been transported into the lignite deposition basin as $\mathrm{Cr}^{3+}$ and $\mathrm{Ni}^{2+}$ in solution from ground or surface waters that drained the ultramafic rock masses at Oropos-Kalamos basin. Similar enrichment mechanisms have been postulated for Nirich lignite $[27,28]$. Furthermore, high $\mathrm{Cr}$ and $\mathrm{Ni}$ contents of natural origin due to the weathering of ultramafic rock masses, ranging from 277 to $404 \mathrm{mg} \mathrm{kg}^{-1}$ and from 246 to $671 \mathrm{mg} \mathrm{kg}^{-1}$, respectively, were also recorded at the coastal sediments of Evoikos Gulf [29].

The presence of pyrite as framboids and as isolated euhedral forms in Oropos-Kalamos bulk-lignite samples supports the hypothesis that pyrite is of syngenetic origin as a result of the reaction between ferrous ions, sulfur ions, and elemental sulfur by bacterial reduction in the reducing deposition 


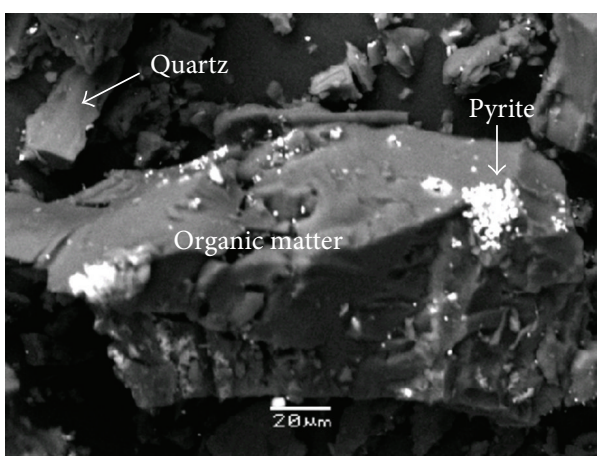

(a)

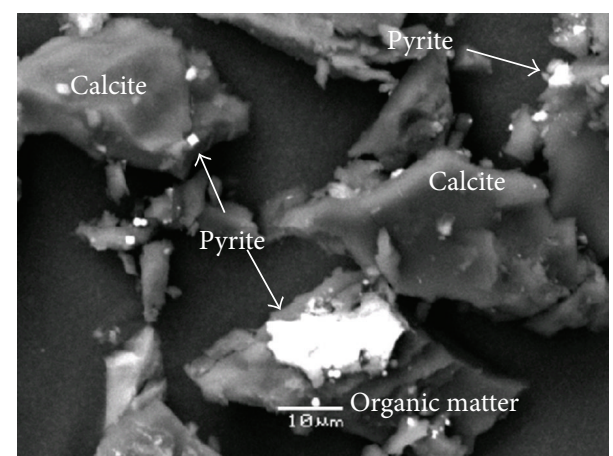

(b)

Figure 4: Modes of occurrence of pyrite in Oropos-Kalamos lignite of Upper Miocene age (SEM backscattered electron images). (a) Pyrite as framboid, organic matter, and quartz; (b) pyrite as euhedral, calcite, and organic matter.

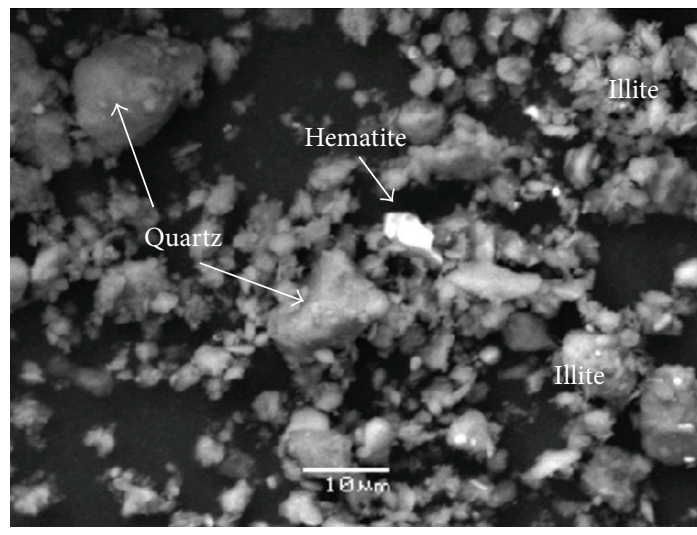

(a)

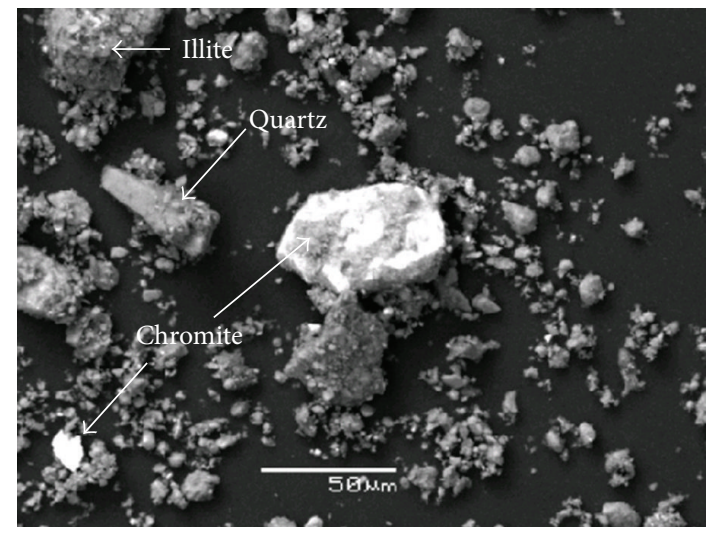

(b)

FIGURE 5: SEM images of chromiferous iron ore occurrences of Oropos-Kalamos area showing (a) hematite, illite, and quartz and (b) chromite, illite, and quartz.

environment. It could be suggested that the mechanism of pyrite $\left(\mathrm{FeS}_{2}\right)$ formation in the lignite of the study area is illustrated by the following reactions:

$$
\begin{gathered}
2 \mathrm{Fe}^{3+}+\mathrm{S}^{2-} \longrightarrow \mathrm{S}^{0}+2 \mathrm{Fe}^{2+}, \\
\mathrm{Fe}^{2+}+\mathrm{HS}^{-} \longrightarrow \mathrm{FeS}+\mathrm{H}^{+}, \\
\mathrm{FeS}+\mathrm{S}^{0} \longrightarrow \mathrm{FeS}_{2} .
\end{gathered}
$$

Furthermore, occurrences of pyrite in framboidal and euhedral forms have been also recorded in lignite deposits of Plakias-Lefkogia, Greece [30], and only as framboidal form in molassic sediments of the Evros area, Greece [31]. Pyrite of syngenetic origin in lignite is also reported for Yashan coalfield, China [32], and Megalopolis basin, Greece [33]. The absence of As from pyrite supports the hypothesis that As which is recorded in the bulk lignite samples of OroposKalamos is mainly associated with the organic matter.

The mean values of the chemical composition of OroposKalamos samples and the calculated enrichment factors are tabulated in Table 1.
The mean concentrations of $\mathrm{As}, \mathrm{Cr}, \mathrm{Hg}, \mathrm{Ni}, \mathrm{Sb}, \mathrm{U}$, and $\mathrm{V}$ in the Oropos-Kalamos lignite were significantly higher than those in the Elassona lignite given by Pentari et al. [34] (Table 1). Furthermore, the elements As, $\mathrm{Co}, \mathrm{Cr}, \mathrm{Cu}$, $\mathrm{Mn}, \mathrm{Mo}, \mathrm{Sb}, \mathrm{Sc}, \mathrm{Se}, \mathrm{U}$, and $\mathrm{V}$ contents were higher than those in the World Coal reported by Clarke and Sloss [35]. Compared to the crustal average, the elements $\mathrm{As}, \mathrm{Cr}, \mathrm{Hg}$, $\mathrm{Mo}, \mathrm{Ni}, \mathrm{Sb}$, and $\mathrm{U}$ contents of lignite show enrichment factors varying between 2.1 and 3337.5 (Table 1). Enrichment factor (EF) is defined as the ratio of a measured element content to that of crustal average. The composition of the Earth's crust, reported by Mason and Moore [36], has been used for the calculations of enrichment factors. An element which shows enrichment factor higher than 2 can be considered enriched [34]. Enrichment factors higher than 2 are presented by using bold type characters (Table 1).

The enrichment of As, Hg, Mo, Sb, and $\mathrm{U}$ of the OroposKalamos bulk-lignite samples can be attributed to geothermal activity that took place during the Upper Miocene in the Oropos-Kalamos basin, a fact that can be confirmed by the outcropping of travertine in the study area. Arsenic, $\mathrm{Hg}$, $\mathrm{Mo}, \mathrm{Sb}$, and $\mathrm{U}$ enrichment by geothermal activity has been 


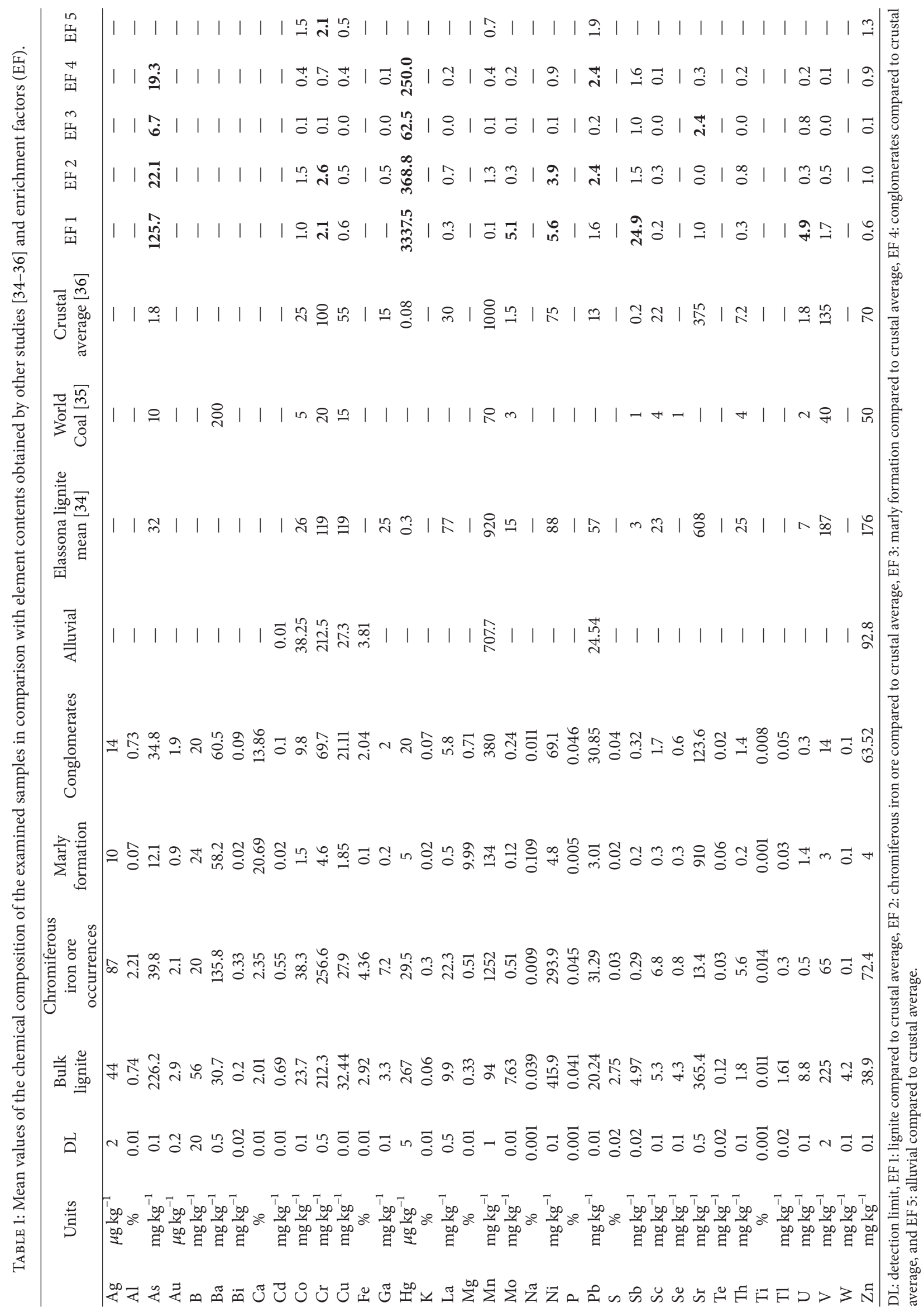


also reported for other Greek lignite, for example, Pentari et al. [34]. Moreover, the $\mathrm{Cr}$ and $\mathrm{Ni}$ enrichment of the bulklignite samples of Oropos-Kalamos basin is associated with ultramafic rock masses observed in the western part of the lignite deposition basin.

The elements $\mathrm{As}, \mathrm{Cr}, \mathrm{Hg}, \mathrm{Ni}$, and $\mathrm{Pb}$ concentrations appear to be highly enriched in the chromiferous iron ore occurrences, while the elements $\mathrm{Co}, \mathrm{Mn}, \mathrm{Sb}$, and $\mathrm{Zn}$ present enrichment factors ranging from 1.0 to 1.5. The elements As, $\mathrm{Hg}$, and $\mathrm{Sr}$ can be considered enriched in marly formation (Table 1). Furthermore, the elements $\mathrm{As}, \mathrm{Hg}$, and $\mathrm{Pb}$ contents in conglomerates can also be considered enriched, while the content of $\mathrm{Sb}$ is higher than that of the Earth's crust [36]. Chromium appears to be enriched in the alluvial deposits, while $\mathrm{Co}, \mathrm{Pb}$, and $\mathrm{Zn}$ show concentrations higher than the Earth's crust (enrichment factors between 1.3 and 1.9) (Table 1). Since there are no known industrial sources of trace element contamination in the study area, the anthropogenic origin of elevated element contents such as $\mathrm{As}, \mathrm{Cr}, \mathrm{Cu}, \mathrm{Hg}$, $\mathrm{Mo}, \mathrm{Pb}, \mathrm{U}$, and $\mathrm{V}$ can be excluded.

In the study area, the heavy influence of the composition of the rocks and sediments on the groundwater quality is recorded by our previous study [14]. Furthermore, Stamatis et al. [14] reported elevated As (up to $246 \mu \mathrm{g} \mathrm{kg}^{-1}$ ), $\mathrm{Cr}^{6+}$ (up to $28 \mu \mathrm{g} \mathrm{kg}^{-1}$ ), $\mathrm{Cr}_{\text {total }}$ (up to $34 \mu \mathrm{g} \mathrm{kg}^{-1}$ ), Fe (up to $2486 \mu \mathrm{g}$ $\mathrm{kg}^{-1}$ ), Mn (up to $132 \mu \mathrm{g} \mathrm{kg}^{-1}$ ), U (up to $14 \mu \mathrm{g} \mathrm{kg}^{-1}$ ), V (up to $19 \mu \mathrm{g} \mathrm{kg}^{-1}$ ), and $\mathrm{Zn}$ (up to $974 \mu \mathrm{g} \mathrm{kg}^{-1}$ ) concentrations in Oropos-Kalamos groundwater.

\section{Conclusions}

The syngenetic origin of pyrite in lignites of Oropos-Kalamos basin is supported by its presence as framboids and as isolated euhedral forms. The absence of As from pyrite supports the hypothesis that As is mainly associated with the organic matter of lignite. Concentrations of potentially hazardous elements such as $\mathrm{As}, \mathrm{Cr}, \mathrm{Hg}, \mathrm{Mo}, \mathrm{Ni}$, Sb, and $\mathrm{U}$ are highly enriched in the Oropos-Kalamos lignite compared to crustal element averages. The mean contents of As, $\mathrm{Cr}, \mathrm{Sb}, \mathrm{U}$, and $\mathrm{V}$ in the Oropos-Kalamos lignite were significantly higher than those reported for the Elassona lignite (Greece) and the World Coal. The distribution of trace elements in the Oropos-Kalamos lignite shows that the enrichment of $\mathrm{Cr}$ and $\mathrm{Ni}$ can be attributed to the known ultramafic rock masses surrounding the lignite basin, while enrichment of As, Hg, $\mathrm{Mo}, \mathrm{Sb}$, and $\mathrm{U}$ of Oropos-Kalamos lignite is associated with the past geothermal activity of Upper Miocene. Nickel and $\mathrm{Cr}$ were transported into the Oropos-Kalamos lignite deposition basin by rivers and streams draining ultramafic rock bodies. Therefore the high contents of As, $\mathrm{U}$, and V in the OroposKalamos lignite result in the high As, U, and V contents in the groundwater. The observation of elevated mean contents of $\mathrm{As}, \mathrm{Hg}, \mathrm{Pb}$, and $\mathrm{Sb}$ in all the examined rock and sediments, in combination with the lack of known industrial source of contamination, indicates the natural source of contamination in the area studied.
The results of this study imply the natural source of $\mathrm{Cr}^{3+}$ and $\mathrm{Cr}^{6+}$ contamination of the Oropos-Kalamos groundwater since high chromium contents were recorded also in the Oropos-Kalamos lignite, chromiferous iron ore occurrences, and alluvial deposits, indicating $\mathrm{Cr}$ leaching and transportation by rivers and ephemeral streams to the depositional basin dating from the Upper Miocene age (about 15 million years ago).

Future work could focus on assessing the risk at the Oropos-Kalamos basin by applying a soil geochemical survey and delineating the spatial variability of the total element soil contents as well as their bioavailable fraction. The risks posed to humans, grazing animals, and other organisms from exposure to the concentrations of trace elements should be further investigated.

\section{Conflict of Interests}

The authors declare that there is no conflict of interests regarding the publication of this paper.

\section{Acknowledgment}

The authors would like to thank the staff of the Department of Economic Geology and Geochemistry, National and Kapodistrian University of Athens, for cooperation during the XRD and SEM analyses.

\section{References}

[1] D. Alexakis, "Assessment of water quality in the MessolonghiEtoliko and Neochorio region (West Greece) using hydrochemical and statistical analysis methods," Environmental Monitoring and Assessment, vol. 182, no. 1-4, pp. 397-413, 2011.

[2] D. Alexakis, D. Gotsis, and S. Giakoumakis, "Assessment of drainage water quality in pre- and post-irrigation seasons for supplemental irrigation use," Environmental Monitoring and Assessment, vol. 184, no. 8, pp. 5051-5063, 2012.

[3] V. Cappuyns and E. Slabbinck, "Occurrence of vanadium in Belgian and European alluvial soils," Applied and Environmental Soil Science, vol. 2012, Article ID 979501, 12 pages, 2012.

[4] D. Gamvroula, D. Alexakis, and G. Stamatis, "Diagnosis of groundwater quality and assessment of contamination sources in the Megara basin (Attica, Greece)," Arabian Journal of Geosciences, vol. 6, no. 7, pp. 2367-2381, 2013.

[5] K. Papadopoulou-Vrynioti, D. Alexakis, G. D. Bathrellos et al., "Distribution of trace elements in stream sediments of Arta plain (western Hellas): the influence of geomorphological parameters," Journal of Geochemical Exploration, vol. 134, pp. 17-26, 2013.

[6] V. A. Tsihrintzis, H. R. Fuentes, and R. K. Gadipudi, “GIS-aided modeling of nonpoint source pollution impacts on surface and ground waters," Water Resources Management, vol. 11, no. 3, pp. 207-218, 1997.

[7] D. Alexakis, D. Gotsis, and S. Giakoumakis, "Evaluation of soil salinization in a Mediterranean site (Agoulinitsa district-West Greece)," Arabian Journal of Geosciences, 2014.

[8] D. Alexakis and G. Tsakiris, "Drought impacts on karstic spring annual water potential. Application on almyros (Crete) brackish 
spring," Desalination and Water Treatment, vol. 16, no. 1-3, pp. 229-237, 2010.

[9] G. C. G. dos Santos, G. S. Valladares, C. A. Abreu, O. A. de Camargo, and C. R. Grego, "Assessment of copper and zinc in soils of a Vineyard region in the state of São Paulo, Brazil," Applied and Environmental Soil Science, vol. 2013, Article ID 790795, 10 pages, 2013.

[10] A. Kelepertsis, D. Alexakis, and I. Kita, "Environmental geochemistry of soils and waters of Susaki area, Korinthos, Greece," Environmental Geochemistry and Health, vol. 23, no. 2, pp. 117$135,2001$.

[11] A. Loukas, "Surface water quantity and quality assessment in Pinios River, Thessaly, Greece," Desalination, vol. 250, no. 1, pp. 266-273, 2010.

[12] A. H. Moghimi, J. Hamdan, J. Shamshuddin, A. W. Samsuri, and A. Abtahi, "Physicochemical properties and surface charge characteristics of arid soils in southeastern Iran," Applied and Environmental Soil Science, vol. 2013, Article ID 252861, 11 pages, 2013.

[13] K. Papadopoulou-Vrynioti, D. Alexakis, G. D. Bathrellos, H. D. Skilodimou, D. Vryniotis, and E. Vassiliades, "Environmental research and evaluation of agricultural soil of the Arta plain, western Hellas," Journal of Geochemical Exploration, vol. 136, pp. 84-92, 2014.

[14] G. Stamatis, D. Alexakis, D. Gamvroula, and G. Migiros, "Groundwater quality assessment in Oropos-Kalamos basin, Attica, Greece," Environmental Earth Sciences, vol. 64, no. 4, pp. 973-988, 2011.

[15] M. B. McBride, "Arsenic and lead uptake by vegetable crops grown on historically contaminated orchard soils," Applied and Environmental Soil Science, vol. 2013, Article ID 283472, 8 pages, 2013.

[16] D. Varrica, E. Tamburo, G. Dongarrà, and F. Sposito, “Trace elements in scalp hair of children chronically exposed to volcanic activity (Mt. Etna, Italy)," Science of the Total Environment, vol. 470-471, pp. 117-126, 2014.

[17] W. Salomons, "Biogeodynamics of contaminated sediments and soils: perspectives for future research," Journal of Geochemical Exploration, vol. 62, no. 1-3, pp. 37-40, 1998.

[18] K. Komnitsas and K. Modis, "Soil risk assessment of As and Zn contamination in a coal mining region using geostatisretics," Science of the Total Environment, vol. 164, no. 2-3, pp. 1185-1190, 2009.

[19] K. Komnitsas and K. Modis, "Geostatistical risk estimation at waste disposal sites in the presence of hot spots," Journal of Hazardous Materials, vol. 371, no. 1-3, pp. 190-196, 2006.

[20] A. Vacca, M. R. Bianco, M. Murolo, and P. Violante, "Heavy metals in contaminated soils of the Rio Sitzerri floodplain (Sardinia, Italy): characterization and impact on pedodiversity," Land Degradation \& Development, vol. 23, no. 4, pp. 350-364, 2012.

[21] M. Roy and L. McDonald, "Metal uptake in plants and health risk assessments in metal-contaminated smelter soils," Land Degradation \& Development, 2013.

[22] D. Fernández-Calviño, B. Garrido-Rodríguez, J. E. LópezPeriago, M. Paradelo, and M. Arias-Estévez, "Spatial distribution of copper fractions in a vineyard soil," Land Degradation \& Development, vol. 24, no. 6, pp. 556-563, 2013.

[23] IGME, Eretria Sheet. Geological Map 1:50000, Department of Geological Maps, Institute of Geology and Mineral Exploration, Athens, Greece, 2000.
[24] G. Pe-Piper and D. Piper, The Igneous Rocks of Greece. The Anatomy of an Orogen, vol. 30 of Beitrage zur Regionalen Geologie der Erde, 2002.

[25] G. Voreadis, "The tertiary lignite basin of Malakasa-Oropos," Geological and Geophysical Surveys, vol. 2, pp. 141-180, 1952 (Greek).

[26] M. Bossard, J. Feranec, and J. Otahe, CORINE Land Cover Technical Guide: Addendum 2000, European Environment Agency, Copenhagen, Denmark, 2000.

[27] A. E. Foscolos, F. Goodarzi, C. N. Koukouzas, and G. Hatziyannis, "Reconnaissance study of mineral matter and trace elements in Greek lignites," Chemical Geology, vol. 76, no. 1-2, pp. 107-130, 1989.

[28] L. Ruppert, R. Finkelman, E. Boti et al., "Origin and significance of high nickel and chromium concentrations in pliocene lignite of the Kosovo basin, Serbia," International Journal of Coal Geology, vol. 29, no. 4, pp. 235-258, 1996.

[29] M. O. Angelidis and M. Aloupi, "Geochemical study of coastal sediments influenced by river-transported pollution: southern Evoikos Gulf, Greece," Marine Pollution Bulletin, vol. 40, no. 1, pp. 77-82, 2000.

[30] N. Koukouzas and S. Skounakis, "Pyrite framboids in the lignite deposits of Plakia-Leufkogia (Rethymnon Crete)," Bulletin of the Geological Society of Greece, vol. 25, no. 2, pp. 193-201, 1991 (Greek).

[31] K. Michailidis, G. Trontsios, and S. Sklavounos, "The occurrence of framboidal pyrite in the onshore molassic sediments of the Evros area, Thrace county, N.E. Greece," in Proceedings of the 2nd Hellenic-Bulgarian Symposium on the Geological and Physicogeographical Problems of the Rhodope Massif, Thessaloniki, Greece, 1980, (Greek).

[32] S. Dai, D. Ren, Y. Zhou et al., "Mineralogy and geochemistry of a superhigh-organic-sulfur coal, Yanshan Coalfield, Yunnan, China: evidence for a volcanic ash component and influence by submarine exhalation," Chemical Geology, vol. 255, no. 1-2, pp. 182-194, 2008.

[33] G. Siavalas, M. Linou, A. Chatziapostolou, S. Kalaitzidis, H. Papaefthymiou, and K. Christanis, "Palaeoenvironment of seam I in the Marathousa lignite mine, Megalopolis basin (Southern Greece)," International Journal of Coal Geology, vol. 78, no. 4, pp. 233-248, 2009.

[34] D. Pentari, A. E. Foscolos, and V. Perdikatsis, “Trace element contents in the Domeniko lignite deposit, Elassona basin, Central Greece," International Journal of Coal Geology, vol. 58, no. 4, pp. 261-268, 2004.

[35] L. Clarke and L. Sloss, "Trace elements: emissions from coal combustion and gasification," International Energy Agency Report CR/49, London, UK, 1992.

[36] B. Mason and C. B. Moore, Principles of Geochemistry, Wiley, New York, NY, USA, 1982. 

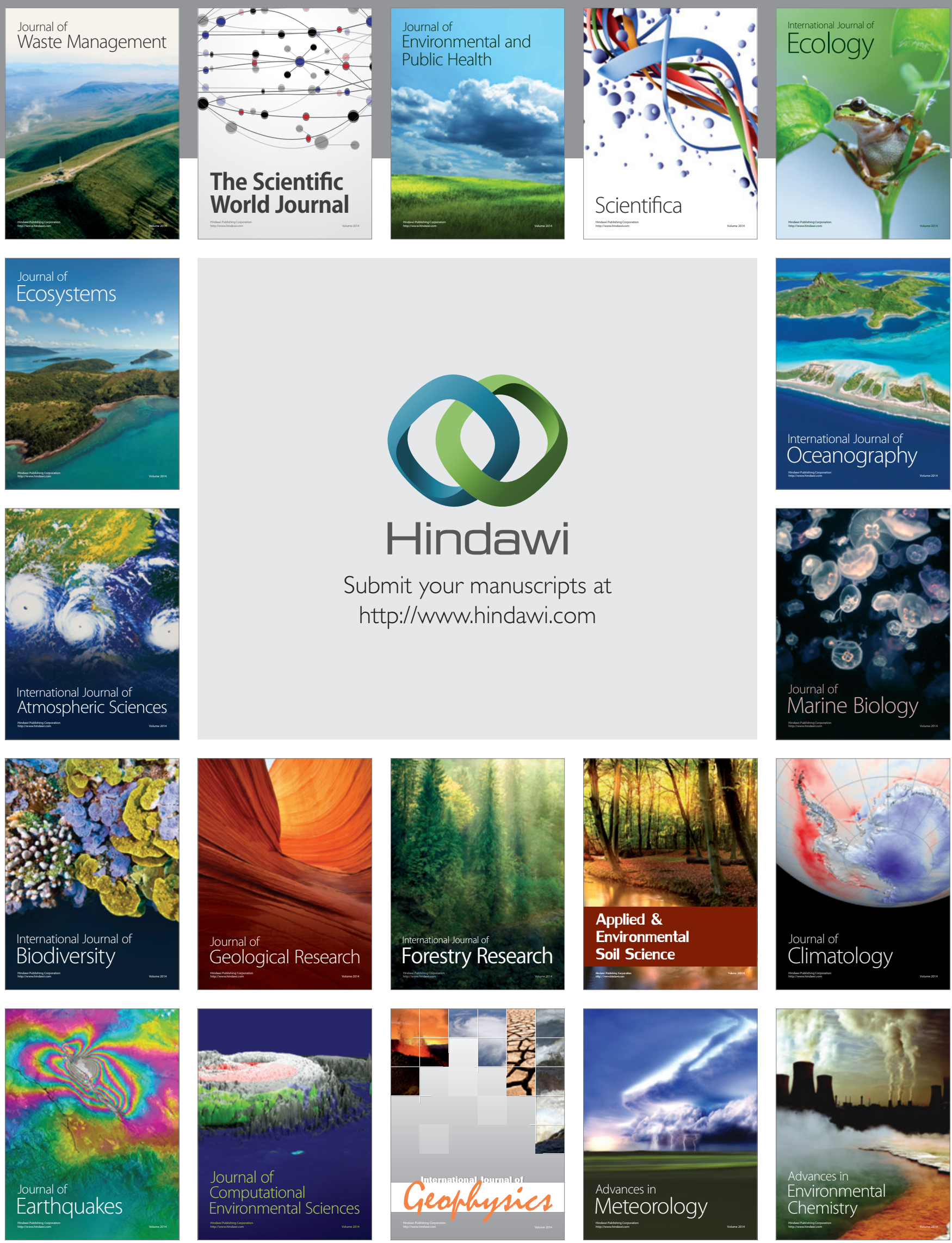